\title{
Saftiflex 保存血にたいする血液保存剤の効果
}

\author{
横浜甫立大学医学部生化学教室 \\ 長野敬中尾順子 \\ 中尾真神保トシ子

\section{EFFECTS OF BLOOD PRESERVATIVES ON STORED BLOOD IN SAFTIFLEX} \\ by \\ Kei Nagano, Toshiko NaKaO, Makoto NakaO and Toshiko Jimbo \\ (Department of Biochemi:try, Yokohama Municipal University, School of Medicine)
}

\begin{abstract}
Abs :ract
Human blood was stored for 8 to 9 weeks in polyethylene storing bags, and the effect of addition of adenine or adenine and inosine to the storing ACD medium was investigated.

When both inosine and adenine were added (AI-blood), normal ATP level was maintained throughout the storage, while the level was falled to as low as one tenth of the normal value when the blood was stored in the usual ACD medium. The addition of only the former compound (A-blood), somewhat protected the ATP level against declination. The effect was, however, much less distinguished than the AT-blood.

The characteristic discoidal shape was also maintained in the AI-blood.

Thus, our previous results, obtained from experiments with usual glass storage bottles, were reconfirmed using polyethylene resavoir bags.
\end{abstract}

中星真等1〉はさきにアデニン，イノシンを $\mathrm{A} \mathrm{C}$ D液に添加した血液保存用液を発表した。この液 は文赤血球のＡＴＰレベルを少なくとも8週間保 つのみならず, 滲透王溶血抵抗, 解糖活性を保 ち, 又中尾喜久内科（群馬大学）々共同研究によ つて輸血後寿命\& A D 保存液, 或いはA C Dに アデニン，或いはイノシンを単独に添加したもの よりも遙かによい成績を示す事が明らかにるれた

\footnotetext{
* 厭生省基準 $\mathrm{B}$ 液に 4 倍量の血液を混じた.
}

2).これらはすべて現行のガラス製保存ビン及び それにシリコン加工をほどこした容器を用いて得 られた結果である. 今回は, 合成樹脂製の容器に よつて各種保存液の効果を比皎した。

\section{実験方法}

カッターラボラトリー社より提供された Saftifiexに，あらかじめ隇菌した次の液を加えておい た.（A） $6.3 \mathrm{ml}$ の $0.9 \% \mathrm{NaCl}$ (B) $6.3 \mathrm{ml}$ の $0.9 \% \mathrm{NaCl}$ にアデニン $6.25 \mathrm{~m} \mathrm{~mole} / 1$ 血液 (C) $6.3 \mathrm{ml}$ の $0.9 \% \mathrm{NaCl}$ にアデニン 6.25 , イノシン 15 , (D) $6.3 \mathrm{mi} \mathrm{の} 0.9 \% \mathrm{Na} \mathrm{Cl}$ アデニン $12.5 \mathrm{nM}$ ， イノシン $27 \mathrm{mM}$ を添加した もの.

通常の A C D 保存血を A,B,C,D, 容器に $50 \mathrm{ml}$ ずつ分注し， $4{ }^{\circ} \mathrm{C} に 8 \sim 9$ 週間保存し，各種の検 索を行なつた。

A T P の測定は, $20 \mathrm{ml}$ の血液をとり, 逗心分 離により血漿を除き，3\%泠過塩素酸 $20 \mathrm{ml}$ を 加え全量 $28 \mathrm{ml}$ になる様に合せ，よく㩭挥して 後遠心分離, 上清 $5 \mathrm{ml}$ をとり $\mathrm{KOH}$ で中和, 10 $\mathrm{ml}$ として過塩素酸クロル酸カリを除いた後， 4 mlをとりConn Caria 法いより，ATPを 測定した。

A T P 量の計算には，蛋白及び 過塩装酸の沈

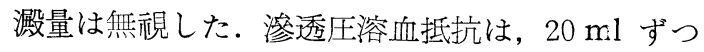
の各種濃度食塩水に $0.1 \mathrm{ml}$ の血液を加え, 1 時 
表 1

\begin{tabular}{|c|c|c|c|c|c|c|c|c|c|}
\hline \multirow{2}{*}{\multicolumn{4}{|c|}{ 添 $\mathrm{mM} / 1$ 加 }} & \multirow{3}{*}{ 保存日数 } & \multicolumn{3}{|c|}{ 測 } & \multicolumn{2}{|l|}{ 值 } \\
\hline & & & & & \multirow{2}{*}{$\begin{array}{l}\text { A T P } \\
\mu \text { mole/ } 100 \\
\text { ml cell }\end{array}$} & \multirow{2}{*}{$\begin{array}{l}\text { 溶血抵抗 } 50 \% \\
\text { 溶血食塩水濃 } \\
\text { 度 }\end{array}$} & \multirow{2}{*}{$\begin{array}{l}0.9 \% \mathrm{NaCl} \\
\text { 中の溶血\% }\end{array}$} & \multicolumn{2}{|c|}{ 乳 酸 量 } \\
\hline & $P$ & $=ン$ & イノシン| & & & & & $\begin{array}{l}\mu \text { mole/ } 100 \\
\text { ml blood }\end{array}$ & $\begin{array}{l}\mu \text { mole / } 100 \\
\text { cell }\end{array}$ \\
\hline 1 & $\begin{array}{l}\text { A } \\
\text { B } \\
\text { C } \\
\text { D }\end{array}$ & \begin{tabular}{l|}
- \\
6.25 \\
6.25 \\
12.5
\end{tabular} & $\begin{array}{l}- \\
\overline{15} \\
27\end{array}$ & $\begin{array}{l}57 \text { 日 } \\
\prime \prime \\
\prime \prime \\
\prime \prime\end{array}$ & $\begin{array}{l}18 \\
41 \\
91 \\
92\end{array}$ & $\begin{array}{l}0.57 \\
0.54 \\
0.52 \\
-\end{array}$ & $\begin{array}{r}17 \\
8.7 \\
5.2 \\
4.8\end{array}$ & & \\
\hline 2 & $\begin{array}{l}\text { A } \\
\text { B } \\
\text { C } \\
\text { D }\end{array}$ & \begin{tabular}{l|}
- \\
6.25 \\
6.25 \\
12.5
\end{tabular} & $\begin{array}{l}- \\
\overline{15} \\
27\end{array}$ & $\begin{array}{l}62 \text { 日 } \\
" 1 \\
" 1 \\
" 1\end{array}$ & $\begin{array}{r}13.2 \\
26.2 \\
88.8 \\
116.1\end{array}$ & $\begin{array}{l}0.535 \\
0.48 \\
0.465 \\
0.46\end{array}$ & $\begin{array}{r}10 \\
5 \\
2 \\
2\end{array}$ & $\begin{array}{l}20.7 \\
23.4 \\
26.9 \\
25.8\end{array}$ & $\begin{array}{l}70.6 \\
71 \\
94.4 \\
94.5\end{array}$ \\
\hline
\end{tabular}

間経過後遠心分離器にかけ上清の $540 \mathrm{~m} \mu$ におけ る吸引を測定し， $540 \mathrm{~m} \mu$ 吸収一食塩水濃度曲線 より，50\%溶血值を求めた。 $0.9 \%$ 食塩水に浮遊 させて得た上清の吸収より, 全へモグロビン濃度 に対する上清の溶血度を算出し, かりに溶血の值 とした。

全血中の乳酸は Barker, Summerson によつ た。

ヘマトクリットはウイントロープ管を用いて測 定した。

\section{結果及び考察}

結果は表 1 に示した。即ち， $\mathbf{A T P}$ P量は $\mathrm{A} \mathrm{C} \mathrm{D}$ 保存血が $8 \sim 9$ 週後に新鮮血の $1 / 5 \sim 1 / 10$ になつて いるのに反して，アデニン単独添加血は $1 / 3$ 位を 残しているが，アデニンとイノシン両者添加のも のは目立つた変化を示していない，なお赤血球の 形状はAは球形，Bは金米糖状が多いのに反し C 及びDは円盤状ないし連銭状であつた。

乳酸発生量はイノシンを添加したものに多く認 められる、ピルビン酸の増量を測定していないの で，決定的なことは言えないが，イノシンの消費 にもとづくものであろう。

$0.9 \%$ 食塩水で稀釈した後の medium に残つ たへモグロビン量をもつて溶血值とかりに稱する と，A,B,C,D の間にはそれぞれ大きな差があつ た。しかしながら，溶血抵抗は明らかに A,B,C,D の間に差を示した。従つてアデニン，イノシン添 加は少くとも in vitro で極めて顕著な保存効果
をもたらすという中尾等の結果がプラスチックバ ックを用いても示された。 しかしながら 8 〜週 後赤血球の滲透圧に対する抵抗值が，全体とし て，前報よりもいさ〉か低下している様に思われ るが，これは職業的供血者の血液を被検液に用い たためであろうと思われる，Gabrio 等によると 大血液で幼弱赤血球は保存に対する抵抗が弱い。 中尾喜久等によると，職業供血者を用いた時より も学生より採血した場合の方が長期保存後の輸血 後寿命が長いであろう事が示唆されている，今後 検討したい.

\section{要 約}

以上, プラスチック容器を用いて A C D , A C D +アデニン, A C D +アデニン十イノシンの人血 液長期保存に対する保存効果を, 赤血球の代謝と 溶血抵抗につきしらべたが，その効果は 3 者の間 に極めて顕著な差が示された。これら保存液の超 長期保存の効果はガラス保存ビンにシリコン樹脂 加工した保存ビンを用いた場合と本質的な差は示 されなかつた。しかしプラスチック容器はその取 披い上極めて軽便であり，その利点を再確認した。

\section{文献}

1) M. Nakao et al.: Proc. Japan Acad. 36, 43 (1960), 第 8 回国際輸血学丟議事録 (印刷中).

2) T. Wada et al.: Proc. Japan Acad., 36, 618 (1960).

3) W.E. Cohn \& C.E. Carter: J. Am. Chem. Soc., 72, 4273 (1651).

4) S.B. Barker \& W.H. Summerson: J. Biol. Chem. 138, 535 (1941).

5) K. Nakao et al.: 第 9 回日本輸血学会（仙台 1961). 